\title{
Analysis of Post-harvest Losses of Banana and the Economic Wellbeing of Farmers in Boyo Division, North West Region of Cameroon
}

\author{
${ }^{*}$ Nkwain, K. T1 , Odiaka, E. C ${ }^{2}$ Ikwuba, A. A I $^{3}$ Nkwi, G. E. ${ }^{4}$ \\ ${ }^{1}$ Centre for Food Technology and Research (CEFTER), \\ Benue State University, \\ Makurdi, Nigeria
}

${ }^{2}$ Department of Agricultural Extension and Communication, Federal University of Agriculture, Makurdi, Nigeria

${ }^{3}$ Department of Sociology, Benue State University, Makurdi, Nigeria

${ }^{4}$ Department of Agricultural Economics and Extension, Federal University Dutse, Jigawa State, Nigeria

Email: kelvinnkwaintoh@gmail.com

\begin{abstract}
Post-harvest losses of banana affect the economic wellbeing of farmers in Africa especially in Boyo Division in the North West region of Cameroon where majority of the producers are smallholders' farmers. The study analysed post-harvest losses of banana and its effect on the economic wellbeing of farmers in Boyo Division. Three hundred and eighty respondents were selected from three out of four sub-divisions in Boyo Division using a multi-stage sampling procedure. Data was obtained from the respondents with the aid of questionnaire and focus group discussions. The data obtained was analysed using descriptive statistics. The results revealed that 61,055 bunches of banana were harvested, 21,107 bunches sold, 16,751 bunches used by farmers' households while 23,197 bunches were lost at postharvest stages in 2019/2020. This quantity lost was suffered at the farm level, transportation, storage, ripening, processing and sale stages with most losses (11-20) suffered at the farm level. The study further revealed that farmers expected an estimated net amount of 10,570,036 FCFA while an estimated net amount of 2,213,759 FCFA was achieved with post-harvest losses. The study therefore, concludes that post-harvest losses of banana have a positive correlation on farmers' economic wellbeing and recommends sensitization and training of farmers on post-harvest management techniques.
\end{abstract}

Keywords: Post-harvest losses, Economic wellbeing, Smallholders' farmers and Banana 


\section{INTRODUCTION}

Post-harvest losses of banana affect the economic wellbeing of farmers globally especially in Africa where production is predominantly carried out by smallholder farmers. Banana is a herbaceous perennial plant that originated from Southeast Asia, New Guinea and Indian subcontinent. It is the second largest produced fruit and eighth most important food crop in the world (Jalawadi et al. 2021; Thangavelu et al. 2021). Africa cultivates over four (4) million hectares of banana and produces about $25 \%$ of the world estimated output and ranked second in terms of global production. Cameroon is one of the highest producers in African-CaribbeanPacific (ACP) with 2015 annual production estimated at 278,450 tonnes (Koigi, 2016).

Banana production in Cameroon is mostly carried out in seven regions vis: Central, East, Littoral, South West, North West, West, and South region. According to Jacobsen et al. (2004), in the North West region of Cameroon, banana is ranked first by $43 \%$ of farmers as the most important food and cash crop. Banana production in this region is typically carried out by smallholder farmers who cultivates predominantly Achu, Gros Michel, Cavendish and Mysore bananas. A significant proportion of these varieties of bananas especially Achu produced in Boyo Division are primarily for sale to consumers from the regional headquarters in Bamenda where it is pounded with corms of cocoyams as a delicacy to feed the fast growing population. Despite the importance of banana in the region and Cameroon at large, it still suffers post-harvest losses along the supply chain. According to Cauthen et al. (2013), 30-50\% of bananas and plantains are lost at post-harvest stages in Cameroon, Nigeria and Ghana. These losses affect the revenue of the farmers.

In Boyo Division, after harvesting and gathering, bananas are transported to the sale points while some are stored, ripened or processed locally before sale. Farmers faces several challenges handling fruits along these stages ranging from inexperience, poor harvesting tools and transportation facilities to lack of improved preservation/storage and ripening facilities. Equally, the socio-political crises (Anglophone crises) that has been lingering for close to four years poses an adverse effect on banana farmers in this division. All these factors contribute to both qualitative and quantitative losses of banana which in turn affect the income of the farmers.

However, for over 20 years, research on bananas in Boyo Division and Cameroon at large have been skewed towards agronomy with little emphasis on post-harvest losses and the economic wellbeing of the smallholder farmers to inform policy makers. Jacobsen et al. (2004) analysed Musa-based cropping systems of the Cameroon highlands (West and North West region) and focused predominantly on pest and diseases. Okolle et al. (2009) investigated banana entomology in Cameroon with emphasis equally on pest and diseases. Newilah et al. (2005) assessed the processing and food uses of bananas in Cameroon and ended with different forms which banana is processed into. These observations shows that little has been done with regard to analysing post-harvest losses of banana and the wellbeing of farmers in Boyo division which informs this study.

\section{STUDY AREA}

Boyo Division is located in the North West region of Cameroon and made up of four administrative Sub-Divisions (Fundong, Njinikom, Belo and Fonfuka). It is located between latitudes $6^{\circ} 9^{\prime}$ and $6^{\circ} 17^{\prime} \mathrm{N}$ and between longitudes $10^{\circ} 16^{\prime}$ and $10^{\circ} 20^{\prime} \mathrm{E}$ and shares territorial limits with five out of the seven Divisions that make up the North West region of Cameroon (Menchum, Donga-Mantung, Bui, Ngoketunjia and Mezam divisions). Although BUCREP 
(2005), stated that the population of Boyo stands at 124, 887 inhabitants based on 2005 census, the 2020 estimated population of Boyo Division based on $2.6 \%$ population growth rate in Cameroon is about 183,539 inhabitants over a total surface area of $1592 \mathrm{~km}^{2}$. Boyo Division is selected due to the diversity of Musa spp. cultivated, the significant quantity produced and the varied stages produce passes through before reaching the consumers.

\section{METHOD OF DATA COLLECTION}

Qualitative and quantitative data were obtained through questionnaire and Focus Group Discussions. Three hundred and eighty open and close ended questionnaires were administered to banana farmers in 12 villages (Baingo, Jinkfin, Sho, Ntum, Yang, Tinifoinbi, Wombong, Mugheff, Abuh, Alim, Bolem and Meli), four villages per Sub-division drawn from three Sub-divisions (Belo, Njinikom, and Fundong). The Sub-divisions and the villages were selected using purposive and systematic sampling techniques with the aid of extension agents and Sub-divisional Delegates of Agriculture based on the quantity of banana they produced. Simple random sampling was employed to select banana farmers. One focus group discussions was organised per Sub-division: one composed of eight females and the remaining two made up of seven and ten males to prevent gender domination. This was to obtain in-depth inquiries on post-harvest losses of banana and the effect on the economic (income) wellbeing of the farmers.

\section{Method of data analysis}

Data obtained were analysed using descriptive statistics. Means were calculated using equation (1) while post-harvest losses (PHL) and mean seasonal net earnings (MSNE) of farmers were calculated using equation (2) and (3).

$\operatorname{Mean}(\tilde{x})=\frac{\Sigma m f}{n}$

Where $\mathrm{m}$ is the midpoint, $\mathrm{f}$ is the frequency, $\sum \mathrm{mf}$ is the sum of the product of the midpoints and frequencies, and $\mathrm{n}$ is the total number of values.

$P H L=T A M Q H-(T A M Q S+T A M Q U)$

$M S N E=M S G E-M S C P$

Where PHL is post-harvest losses of banana, TAMQH is the total average mean quantity of banana harvested while TAMQS and TAMQU are the total average mean quantity of banana sold and total mean quantity of banana used by farmers' households respectively. MSGE and MSCP represent mean seasonal gross earning and mean seasonal cost of production respectively.

\section{RESULTS AND DISCUSSION}

Quantity of banana harvested on an average of 2.05 hectares during 2019/2020 cropping

cycle

Findings on quantity of banana harvested revealed that banana production in the study area was in seasons (surplus and scarce seasons). According to focus group reports, surplus season ranges from January to March and from September to December (seven months) while the scarce season ranges from April to August (five months). Further inquiries revealed the chief reason for the scarcity of banana during this season was that only few fruited stems typically endure the warm and harsh conditions of the dry season (December-February). Additionally, as a result of shortage of water in the dry season, most of the non-fruited and fruited bananas consist of smaller stems as well as bunches. At the beginning of the rainy season (mid-March 
or early April), the first storm often come and blow majority of them off. Then from April to August, new plants will be fruiting after recovering from the dry season and storm stress while pending maturity as from September. Gros Michel was indicated to be the scarcest variety of banana during the scarcity period. This was due to the susceptibility of this variety to drought as well as storm as a result of its tall nature.

These seasons equally have an effect on post-harvest losses of bananas. It was revealed that the first surplus season (January to March) occurs in the heart of the dry season especially February and early March when there is excessive heat. This heat caused frequent ripening to all the varieties of bananas when not needed. This leads to softening and rotting of fruits resulting to quantitative losses. It was indicated that $A c h u$ has the shortest ripening period when matured consequently, suffers the highest post-harvest losses during this period and this is followed by Cavendish. In the second section of the surplus season (September to December) especially in September, most of the earth roads are bad because this is the month that records the highest torrential rainfall in the study area which is usually accompanied by soil movement and landslides. This contributes to road blockages and several springs flowing across the roads impeding the evacuation of produce from most interior areas thus, increasing both qualitative and quantitative losses at the farm and transport level. The total quantity of banana harvested during scarce and surplus seasons for 2019/2020 cropping cycle is presented in Table 1.

Table 1: Distribution of quantity of banana harvested during 2019/2020 cropping cycle

\begin{tabular}{lll}
\hline Quantity of banana harvested (bunches) & Frequency & Percentage \\
\hline Less than 500 & 140 & 37 \\
$500-1000$ & 149 & 39 \\
$1001-1500$ & 78 & 21 \\
$1501-2000$ & 13 & 3 \\
Total & $\mathbf{3 8 0}$ & $\mathbf{1 0 0}$ \\
\hline
\end{tabular}

Source: Field Survey, 2021

The results in Table 1 indicated that 39\% of the farmers harvested a total of 500-1000 bunches of banana and about 3\% harvested 1501-2000 bunches during 2019/2020 cropping cycle. This implies that most of the farmers $(78 \%)$ harvested $500-1000$ bunches of banana.

\section{Quantity of banana sold and used by farmers' households}

The results in Table 2 on quantity of banana sold revealed that $34 \%$ of the farmers sold 301500 bunches of banana meanwhile only 2\% sold 701-1000 bunches from their harvest. With regard to the total quantity of banana used by the farmers' households, focus group discussions revealed that part of the produce was utilized for consumption and nonconsumption purposes. These quantities consumed and used for non-household consumption purposes were added and presented as shown in Table 2 . The results revealed that $44 \%$ of the farmers used 100-300 bunches of their produced for consumption and non-consumption purposes while 3\% used 501-700 bunches of banana.

Focus group report revealed that the quantity of banana utilized for non-household consumption purposes were given to friends and relatives, used for charity and payment inkind as well as for feeding of animals. Farmers shared part of their produced with friends/relatives as well as orphans who are in need during food scarcity seasons which typically depicts the social cohesion and unbounded generosity of the people of the study area. Farmers equally entertain visitors with one or two hands of ripe bananas which are either taken home or eaten in the course of discussion. This shows that apart from commercialisation 
and consumption, farmers equally have other responsibilities to fulfil with their produced which makes them committed members of their society thus, contributing to the wellbeing of the communities. Meanwhile, other farmers used part of their produced as a reward for labour and a way of motivating others as well as boiling and mixing with animals' feed as a way to reduce cost.

Table 2: Distribution of quantity of banana harvested by purpose in 2019/2020

\begin{tabular}{lcc|}
\hline \multicolumn{1}{c}{ Quantity (bunches) } & \multicolumn{2}{c}{ Purpose } \\
\cline { 2 - 3 } & Sold & Used by farmers' households \\
\hline Less than 100 & $26(101)$ & $40(153)$ \\
$100-300$ & $28(106)$ & $44(167)$ \\
$301-500$ & $34(129)$ & $13(50)$ \\
$501-700$ & $10(39)$ & $3(10)$ \\
$701-1000$ & $2(5)$ & $0(0)$ \\
Total & $\mathbf{1 0 0 ( 3 8 0 )}$ & $\mathbf{1 0 0}(\mathbf{3 8 0})$ \\
\hline
\end{tabular}

Source: Field Survey, 2021

Mean computation for quantity of banana harvested, sold, used by farmers' households and lost

The mean $(\tilde{x})$ computations for quantity of banana sold and used by farmers' households from the quantity produced in 2019/2020 cropping cycle based on the data presented on Table 1 and 2 is as shown in Table 3. This is in a bit to ascertain the quantity of banana that was lost from the quantity that was harvested. Data from the Sub Delegations of Agriculture under study revealed the average weight of the varieties of bananas cultivated in the study area to be $14-16 \mathrm{~kg}$ per bunch. An average weight of $15 \mathrm{~kg}$ is adopted for this study for calculations. Equation (1) and (2) were used to calculate the quantity of banana that were lost at postharvest stages.

Table 3: Mean distribution for quantity of banana harvested, sold, used by farmers' households and lost in 2019/2020

\begin{tabular}{cccc}
\hline $\begin{array}{c}\text { Quantity of banana } \\
\text { harvested (bunches) }\end{array}$ & $\begin{array}{c}\text { Quantity of } \\
\text { banana sold } \\
\text { (bunches) }\end{array}$ & $\begin{array}{c}\text { Quantity of banana used } \\
\text { by farmers' household } \\
\text { (bunches) }\end{array}$ & $\begin{array}{c}\text { Quantity of } \\
\text { banana lost } \\
\text { (bunches) }\end{array}$ \\
\hline 61,055 & 21,107 & 16,751 & 23,197 \\
$100 \%$ & $34.6 \%$ & $27.4 \%$ & $38 \%$ \\
\hline
\end{tabular}

Source: Field Survey, 2021

Findings in Table 3 revealed that an average of 61,055 bunches (915.8 tonnes) of banana were harvested in the study area. Out of this quantity, an average amount of 21,107 bunches (316.6 tonnes) was sold while an estimated amount of 16,751 bunches (251.3 tonnes) was used by the farmers' households. Also, an estimated amount of 23,197 bunches (348 tonnes) of bananas were lost at post-harvest stages. Table 3 further showed that out of $100 \%$ of bananas harvested, $34.6 \%$ were sold, $27.4 \%$ used by farmers' households, while $38 \%$ were lost as illustrated in figure 1 . The figure demonstrated that more than one-third of banana produced in the study area is lost. This therefore, implies that post-harvest losses of banana in the study is high. Further inquiries from focus group discussions revealed that some of the principal causes of the losses were Socio-political crises (Anglophone crises) and COVID-19. During the peak of these crises in 2019/2020, the losses increased to 60-80\%. Equally, the losses recorded resulted from ripening, softening, and rotting of fruits in the farm and at the sale points because there were no ready markets. Additionally, animal destruction, theft of fruits during storage, and finger breakage during loading, transportation, and off-loading constitute avenue through which losses occur. 


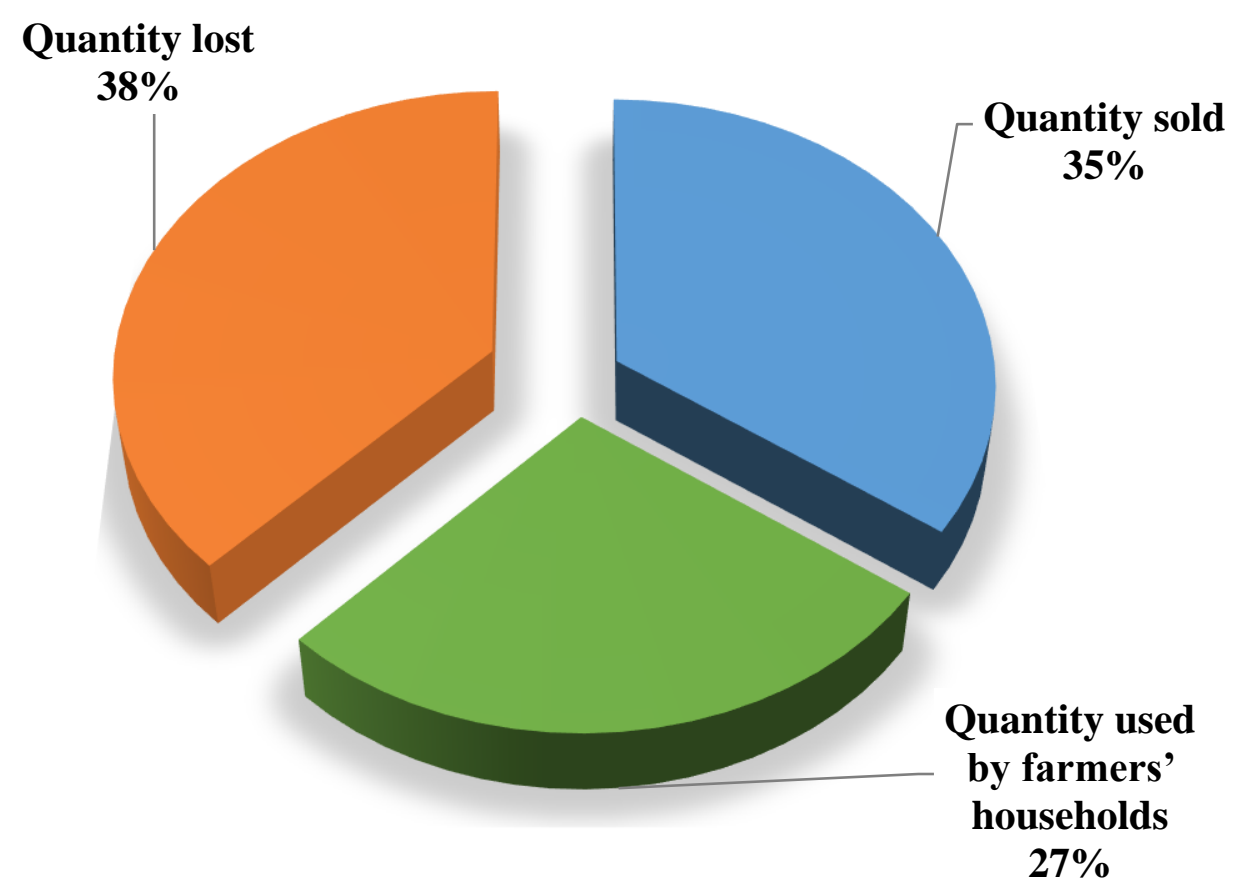

Figure 1: Illustration of the quantity of banana lost

Source: Field Survey, 2021

The proportion of bananas reported to be sold (34.6\%) and used by farmers' households for consumption and non-consumption purposes $(27.4 \%)$ in the study differs with the findings of Nalunga et al. (2015) who reported that in Rwanda, 65\% of bananas were primarily used for consumption while $35 \%$ were for commercialization purposes. Similarly, the results obtained also differs from the findings of Nayak (2018) who reported that an average of $95.53 \%$ of bananas were principally for commercialisation while the remaining $4.46 \%$ were for domestic consumption, kind payment as wages, and relatives and religious purposes. Also the 38\% post-harvest losses of banana recorded in the study area is higher than the value reported by Bantayehu et al. (2018) in North Western Ethiopia who documented 24.1\% losses for banana, tomato, guava, papaya, avocado, and mango at different stages in the supply chain. The results also contradicts submission of Kikulwe et al. (2018) who reported 14.9\% post-harvest losses of bananas in the districts of Rakai, Isingiro and Kampala in Uganda.

\section{Extent of post-harvest losses of banana along the supply chain}

The total post-harvest loss of banana (38\%) were recorded at six (6) different stages along the supply chain as identified by focus groups discussants across the study area. These are: farm level, loading/transporting/off-loading, storing, ripening, processing and sale stages.

Table 4 revealed that at farm stage, in the course of harvesting and gathering as well as abandonment of fruits in the farm, 55\% of the farmers incurred $11-20 \%$ losses. Farmers indicated that losses at this stage were due to hands and fingers breakage resulting from inappropriate harvesting techniques and the sloppy nature of some farms. These harvesting practices were associated to lack of improved harvesting tactics and equipment. These have resulted to producers cutting the stem at an inappropriate position and causing the bunch to fall at an excessive speed and onto the ground leading to breakages. The results obtained agrees with the findings of Mebratie et al. (2015), Woldu et al. (2015), Ssennoga et al. (2019), and Rwubatse et al. (2018) who reported similar range of $17 \%, 15.6 \%$, and $14 \%$ losses for banana output at farm level in Ethiopia and Uganda respectively.

At the transportation stage, losses were estimated at $6-10 \%$ and were said to be associated to poor handling, heaping of bunches and above all poor roads and transport facilities. Produce 
was conveyed using head load, shoulders, baskets, bikes, as well as cars. These facilities had no shock absorber and hence abrasion and browning were experienced. Loading and offloading were carried out roughly leading to bruises and finger breakages. Losses at this stage were equally blamed on rough riding of motor bikes which contributed to mechanical injuries and finger breakages. The result differs from the findings of Ssennoga et al. (2019), Jadhav et al. (2020) and Kumari and Kumar (2018) who documented 15\%, 3.9\% and 1.02\% at this stage in Uganda and India.

Furthermore, the results in Table 4 equally revealed that at the storage stage, losses were suffered at a ratio of $6-10 \%$ and primarily induced by poor storage facilities which were most often invaded by goats and most especially, the inability to control heat which led to ripening. The result differs from the observations of Kumari and Kumar (2018) and Jadhav et al. (2020) who reported $0.56 \%$ and $3.4 \%$ bananas losses during storage in India. At the ripening and processing stages, losses were estimated at $1-5 \%$ and were associated to softening and rotting of fruit mainly because some hands were placed on others as well as the use of poor processing facilities. The results obtained agrees with the findings of FAO (2014) which reported an average banana loss of 3\% during ripening in Kenya. Meanwhile, at the sale point or market stage losses were 1-5\% and were mostly qualitative. Farmers blamed these losses to rough handling of fruits and exposure of the fruits to the sun which contributed to browning.

Table 4: Extent of post-harvest losses of banana along the different stages

\begin{tabular}{lllllll}
\hline \multicolumn{1}{c}{$\begin{array}{c}\text { Extent of } \\
\text { PHLs }\end{array}$} & \multicolumn{7}{c}{ Stages } \\
\cline { 2 - 7 } & Farm & Transportation & Storage & Ripening & Processing & Sale point \\
\hline $1-5$ & $15(57)$ & $22(84)$ & $44(169)$ & $65(246)$ & $6(24)$ & $86(327)$ \\
$6-10$ & $20(76)$ & $40(155)$ & $50(189)$ & $6(22)$ & $1(01)$ & $14(53)$ \\
$11-20$ & $55(210)$ & $31(117)$ & $2(06)$ & $00(00)$ & $00(00)$ & $00(00)$ \\
$21-40$ & $7(27)$ & $5(18)$ & $00(00)$ & $00(00)$ & $00(00)$ & $00(00)$ \\
$41-60$ & $2(07)$ & $1(04)$ & $00(00)$ & $00(00)$ & $00(00)$ & $00(00)$ \\
$61-80$ & $1(03)$ & $1(02)$ & $00(00)$ & $00(00)$ & $00(00)$ & $00(00)$ \\
Do not take & $00(00)$ & $00(00)$ & $4(16)$ & $29(112)$ & $93(355)$ & $00(00)$ \\
part & & & & & & \\
Total & $\mathbf{1 0 0 ( 3 8 0 )}$ & $\mathbf{1 0 0 ( 3 8 0 )}$ & $\mathbf{1 0 0 ( 3 8 0 )}$ & $\mathbf{1 0 0 ( 3 8 0 )}$ & $\mathbf{1 0 0 ( 3 8 0 )}$ & $\mathbf{1 0 0 ( 3 8 0 )}$ \\
\hline
\end{tabular}

Source: Field Survey, 2021

Effect of post-harvest losses of banana on the economic wellbeing of the Farmers

The amount of money presented in Table 5 represents the total estimates of what farmers spent in the course of production. That is the aggregate amount of money spent on suckers, transplanting, clearing, pruning, insecticides and herbicides, rents, cost of harvesting and transportation in 2019/2020 cropping cycle.

Table 5: Cost of banana production on an average of 2.05 ha for 2019/2020 cropping cycle

\begin{tabular}{lll}
\hline Cost of production (FCFA) & Frequency & Percentage \\
\hline Less than 50,000 & 239 & 63 \\
$50,000-100,000$ & 100 & 26 \\
$100,001-150,000$ & 24 & 6 \\
$150,001-200,000$ & 13 & 3 \\
200,001 and above & 4 & 2 \\
Total & $\mathbf{3 8 0}$ & $\mathbf{1 0 0}$ \\
\hline
\end{tabular}

1 FCFA $=0.0017$ USD

Source: Field survey, 2021

The results in Table 5 indicated that a significant proportion, $63 \%$ of the farmers spent less than 50,000 FCFA on banana production while only $2 \%$ spent 200,001 FCFA and above. These results signify that banana production in the study area does not require much inputs especially for existing farms. Field observation in addition to focus group report revealed that 
almost all the farmers do not apply fertilizers reason why the cost of production is low. Focus group members further reported that higher inputs were used only in the first years of cultivation and once the farm stabilizes, little were needed as much effort were only focused on clearing, pruning, harvesting, transportation, and to a lesser extent replacement of dead plants.

\section{Expected income of banana farmers with minimal losses}

The expected income of banana farmers when post-harvest losses of banana were minimal is as shown in Table 6. Mayienga and Cachia (2021) estimated minimum post-harvest losses of fruits in Western Africa as $17.1 \%$. However, the present study considered $10 \%$ as minimum post-harvest losses of banana in the study area. This is due to the fact that banana is one of the fruits with a lower moisture content. Equally, the study area is predominantly cooled especially in the rainy season with average temperature of $26.5^{\circ} \mathrm{C}$. Most of the months of the year especially from April to November records lower temperatures which sometimes go down to $15^{\circ} \mathrm{C}$. Hence, this climate reduces the rate of deterioration of banana fruits.

Table 6: Expected income of banana farmers with minimal post-harvest losses

\begin{tabular}{lll}
\hline $\begin{array}{l}\text { Expected income with minimal } \\
\text { losses (FCFA) }\end{array}$ & Frequency & Percentage \\
\hline Less than 100,000 & 34 & 9 \\
$100,000-200,000$ & 115 & 30 \\
$200,001-300,000$ & 141 & 37 \\
$300,001-400,000$ & 73 & 19 \\
$400,001-500,000$ & 12 & 3 \\
500,001 and above & 5 & 2 \\
Total & $\mathbf{3 8 0}$ & $\mathbf{1 0 0}$ \\
\hline
\end{tabular}

1 FCFA $=0.0017$ USD

Source: Field survey, 2021

The results in Table 6 revealed that a significant proportion, $37 \%$ of the farmers expected an income of 200,001-300,000 FCFA with minimal losses while $2 \%$ expected 500,001 FCFA and above. This implies that when losses are minimal, banana farmers make more profit.

\section{Income with post-harvest losses}

The results in table 7 showed that, a significant fraction, $52 \%$ of the farmers got 50,000-100,000 FCFA when they suffered losses while only 5\% earned 200,001 FCFA and above with losses. These results indicate a drastic drop in farmers' income due to post-harvest losses. The results were consistent with the views of focus groups members across the study area which maintains that for the past four (4) years, the income of banana producers have dropped as a result of the increase in post-harvest losses of this perishable crop partly because of the Sociopolitical crises which have affected the study area. Similarly, Rwubatse et al. (2018) reported that in Rwanda, qualitatively damaged banana fruits are sold at a price of $25 \mathrm{Rwf}$ (Rwandan franc) per kilogram while healthy or quality fruits are sold at an average of $320 \mathrm{Rwf}$ per kilogram. Therefore, a very high price discount of $295 \mathrm{Rwf}$ is recorded per kilogram because of the losses hence, a reduction in the farmers' income. 
Table 7: Income of banana farmers when post-harvest losses were incurred

\begin{tabular}{lll}
\hline Income with losses (FCFA) & Frequency & Percentage \\
\hline Less than 50,000 & 137 & 36 \\
$50,000-100,000$ & 196 & 52 \\
$100,001-200,000$ & 27 & 7 \\
200,001 and above & 20 & 5 \\
Total & $\mathbf{3 8 0}$ & $\mathbf{1 0 0}$ \\
\hline
\end{tabular}

1 FCFA $=0.0017$ USD

Source: Field survey, (2021)

Mean computation for income with minimal and with post-harvest losses

In order to establish the effect of banana losses on the income of the farmers, mean $(\tilde{\mathrm{x}})$ computation was applied to compute Mean Seasonal Cost of Production (MSCP), Mean Seasonal Gross Earnings (MSGE), Mean Seasonal Net Earnings (MSNE) and profit margin with minimal and with post-harvest losses for 2019/2020 season using equation (1) and (3). The results is as shown in Table 8.

Table 8: Mean distribution for income with minimal and with post-harvest losses

\begin{tabular}{lllll}
\hline Income & MSCP (FCFA) & MSGE (FCFA) & MSNE (FCFA) & $\begin{array}{l}\text { Profit } \\
\text { Margin }\end{array}$ \\
\hline $\begin{array}{l}\text { Expected income with minimal } \\
\text { losses }\end{array}$ & $3,829,980$ & $14,400,016$ & $10,570,036$ & $73 \%$ \\
& & & & \\
Income with post-harvest losses & $3,829,980$ & $6,043,739$ & $2,213,759$ & $36.6 \%$ \\
\hline
\end{tabular}

Source: Field survey, 2021

The results in Table 8 indicated that farmers spent an estimated amount of 3,829,980 FCFA in the course of production. Meanwhile, an average gross income of 14,400,016 FCFA and 6,043,739 FCFA were expected with minimal losses and gotten when there were post-harvest losses respectively. An average net income of 10,570,036 FCFA was expected with minimal losses while an average net amount of 2,213,759 FCFA was obtained when post-harvest losses were incurred. With regards to the profit margin, a 73\% profit margin was expected with minimal losses while $36.6 \%$ was achieved with post-harvest losses. These therefore, means that when there were post-harvest losses, the profit margin of farmers dropped from $73 \%$ to $36.6 \%$.

\section{CONCLUSION AND RECOMMENDATIONS}

The results have revealed that out of the 61,055 (915.8 tonnes) banana bunches harvested, 23,076 bunches (346.1 tonnes) representing 38\% were neither sold or used by farmers' households and therefore, lost at post-harvest stages. Most of the losses (11-20\%) were suffered at the farm stage. The study further revealed a positive correlation between postharvest losses of banana and the economic wellbeing of the farmers as the losses reduced the income of the farmers by $36.4 \%$. Therefore, sensitization and training of farmers on postharvest management techniques are recommended.

\section{ACKNOWLEDGMENT}

The authors wish to acknowledge the Centre for Food Technology and Research (CEFTER) for financial support. 


\section{REFERENCES}

Bureau Central des Recensements et des Etudes de Population (BUCREP), (2005). Répertoire actualisé des villages du Cameroun. Troisième Recensement Général de la Population et de l'Habitat du Cameroun, Volume IV - Tome 07, pp. 435.

Cauthen, J., Jones, D., Gugerty, M. K., \& Anderson, C.L. (2013). Banana and Plantain Value Chain: West Africa EPAR Brief No. 239. Prepared for the Agricultural Policy Team of the Bill \& Melinda Gates Foundation, pp. 25.

Food and Agricultural Organisation (FAO). (2014). Food Loss Assessments: Causes and Solutions Case Studies in Small-scale Agriculture and Fisheries Subsectors in Kenya. Global Initiative on Food Loss and Waste Reduction-Save Food-Food \& Agriculture Organization of the United Nations, Rome, Pp. 89.

Jacobsen, K., Fogain, R., Mouassom, H., \& De Waele, D. (2004). Musa-based cropping systems of the Cameroon highlands: a case study of the West and Northwest provinces of Cameroon, with emphasis on nematodes. Fruits, 59(5): 311-318.

Jadhav, R. J., Shaikh, N. B., Pawar, K. B., Mendhe, A. R., \& Chaure, J. S. (2020). Assessment of post-harvest losses in banana under Jalgaon condition, in Maharashtra. International Journal of Chemical Studies, 8(3): 889-892.

Jalawadi, S., Jagadeesh, R. C., Naik, N., Basavaraj, N., Kantharaju, V. et al. (2021). Studies on organoleptic evaluation of banana genotypes. Journal of Pharmacognosy and Phytochemistry, 10(1): 553-556.

Kikulwe, E. M., Okurut, S., Ajambo, S., Nowakunda, K., Stoian, D. et al. (2018). Postharvest Losses and their Determinants: A Challenge to Creating a Sustainable Cooking Banana Value Chain in Uganda. Sustainability, 10(2381): 1-19.

Koigi, B. (2016). Cameroon top banana producer in Africa-Caribbean-Pacific region. https://africabusinesscommunities.com. Accessed on 18 th January, 2021.

Kumari, P., \& Kumar, S. (2018). A study on post-harvest losses and constraints in banana cultivation in Vaishali district (Bihar). The Pharma Innovation Journal, 7(6): 9395.

Mebratie, M. A., Haji, J., Woldetsadik, K., \& Ayalew, A. (2015). Determinants of Postharvest Banana Loss in the Marketing Chain of Central Ethiopia. Food Science and Quality Management, 37: 52- 63.

Nalunga, A., Kikulwe, E., Nowakunda, K., Ajambo, S., \& Naziri, D. (2015). Structure of the Cooking Banana Value Chain in Uganda and Opportunities for Value Addition and Postharvest Losses Reduction. Technical report: Expanding Utilization of Roots, Tubers and Bananas and Reducing Their Postharvest Losses (RTB-ENDURE), http://www.rtb.cgiar.org/endure, Pp. 40. Accessed on 10 th February, 2020.

Nayak, A. K. (2018). A Study of Post-Harvest Losses of Banana (Musa paradisiaca) Cultivation and its Marketing in District Durg of Chhattisgarh-An Economic Analysis. Doctoral thesis, Sam Higginbottom University of Agriculture, Technology and Sciences, Allahabad, India. Pp.153.

Newilah, G. N., Tchango, J. T., Fokou, É., \& Etoa, F-X. (2005). Processing and food uses of bananas and plantains in Cameroon. Technical Paper, Fruits, 60: 245-253.

Okolle, J. N., Fansi, G. H., Lombi, F. M., Lang, P. S., \& Loubana, P. M. (2009). Banana Etomological Research in Cameroon: How Far and what next? African Journal of Plant Science Biotechnology, 3(1): 1-19.

Rwubatse, B., Kitinoja, L., Mukantwali, C., Kabayiza, E., Chahine-Tsouvalaki, H. et al. (2018). Postharvest Loss Assessment of Green Bananas in Rwanda. Feed the Future. The U.S Government's Global Hunger \& Food Security Initiative. Pp. 73. 
Ssennoga, F., Mugurusi, G., \& Oluka, P. N. (2019). Food insecurity as a supply chain problem. Evidence and lessons from the production and supply of bananas in Uganda. Scientific African 3, pp. 11.

Thangavelu, R., Saraswathi, M. S., Uma, S., Loganathan, M., Backiyarani1, S. et al. (2021). Identification of sources resistant to a virulent Fusarium wilt strain (VCG 0124) infecting Cavendish bananas. Scientific Report, 11: 1-14.

Woldu, Z., Mohammed, A., Belew, D., Shumeta, Z., \& Bekele, A. (2015). Assessment of Banana Postharvest Handling Practices and Losses in Ethiopia. Journal of Biology, Agriculture and Healthcare, 5(17): 82-96. 